medRxiv preprint doi: https://doi.org/10.1101/2020.09.11.20192419; this version posted September 13 , 2020. The copyright holder for this preprint (which was not certified by peer review) is the author/funder, who has granted medRxiv a license to display the preprint in perpetuity.

PLOS ONE Submission It is made available under a CC-BY 4.0 International license.

\title{
Cohort profile: St. Michael's Hospital Tuberculosis Database (SMH-TB), a retrospective cohort of electronic health record data and variables extracted using natural language processing
}

David Landsman ${ }^{1}$, Ahmed Abdelbasit ${ }^{2}$, Christine Wang ${ }^{2}$, Michael Guerzhoy ${ }^{3,4,5}$, Ujash Joshi ${ }^{4}$, Shaun Mathew ${ }^{6}$, Chloe Pou-Prom ${ }^{7}$, David Dai ${ }^{7}$, Victoria Pequegnat ${ }^{8}$, Joshua Murray ${ }^{7}$, Kamalprit Chokar $^{9}$, Michaelia Banning ${ }^{7}$, Muhammad Mamdani ${ }^{5,7,10,11,12}$, Sharmistha Mishra ${ }^{\mathbb{T l}, 1,2,11}{ }^{\text {, Jane }}$ Batt $^{*, I J}, 13,14$

1. MAP Centre for Urban Health Solutions, Li Ka Shing Knowledge Institute, St. Michael's Hospital, Unity Health Toronto, Toronto, Ontario, Canada

2. Department of Medicine, University of Toronto, Toronto, Ontario, Canada

3. Princeton University, Princeton, New Jersey, United States

4. University of Toronto, Toronto, Ontario, Canada

5. Li Ka Shing Knowledge Institute, St. Michael's Hospital, Unity Health Toronto, Toronto, Ontario, Canada

6. Department of Computer Science, Ryerson University, Toronto, Ontario, Canada

7. Unity Health Toronto, Toronto, Ontario, Canada

8. Decision Support Services, St. Michael's Hospital, Unity Health Toronto, Toronto, Ontario, Canada

9. Division of Respirology, Department of Medicine, St. Michael's Hospital, Unity Health Toronto, Toronto, Ontario, Canada

10. Leslie Dan Faculty of Pharmacy, University of Toronto, Canada, Toronto, Ontario, Canada

11. Institute of Health Policy, Management, and Evaluation, University of Toronto, Toronto, Ontario, Canada

12. Vector Institute, Toronto, Ontario, Canada

13. Keenan Research Center for Biomedical Science, St. Michael's Hospital, Unity Health Toronto, Toronto, Ontario, Canada

14. Institute of Medical Science, University of Toronto, Toronto, Ontario, Canada

IT These authors contributed equally to this work.

*Corresponding author: Jane Batt, MD, PhD

E-mail: Jane.batt@utoronto.ca 
medRxiv preprint doi: https://doi.org/10.1101/2020.09.11.20192419; this version posted September 13, 2020. The copyright holder for this preprint (which was not certified by peer review) is the author/funder, who has granted medRxiv a license to display the preprint in perpetuity.

PLOS ONE Submission It is made available under a CC-BY 4.0 International license .

\section{Author Contributions}

36 David Landsman - Data Curation, Formal Analysis, Investigation, Methodology, Software,

37 Validation, Visualization, Writing - Original Draft Preparation, Writing - Review \& Editing

38 Ahmed Abdelbasit - Data Curation, Investigation, Validation, Writing - Original Draft

39 Preparation, Writing - Review \& Editing

40 Christine Wang - Data Curation, Investigation, Validation, Writing - Review \& Editing

41 Michael Guerzhoy - Investigation, Methodology, Software, Writing - Review \& Editing

42 Ujash Joshi - Investigation, Methodology, Software, Writing - Review \& Editing

43 Shaun Mathew - Investigation, Methodology, Software, Writing - Review \& Editing

44 Chloe Pou-Prom - Investigation, Methodology, Software, Writing - Review \& Editing

45 David Dai - Investigation, Methodology, Software, Writing - Review \& Editing

46 Victoria Pequegnat - Data Curation, Resources, Validation, Writing - Review \& Editing

47 Joshua Murray - Investigation, Methodology, Software, Writing - Review \& Editing

48 Kamalprit Chokar - Data Curation, Writing - Review \& Editing

49 Michaelia Banning - Project Administration, Writing - Review \& Editing

50 Muhammad Mamdani - Project Administration, Writing - Review \& Editing

51 Sharmistha Mishra - Conceptualization, Data Curation, Funding Acquisition, Investigation,

52 Methodology, Project Administration, Resources, Supervision, Validation, Writing - Review \&

53 Editing

54 Jane Batt - Conceptualization, Data Curation, Funding Acquisition, Investigation, Methodology,

55 Project Administration, Resources, Supervision, Validation, Writing - Review \& Editing 
medRxiv preprint doi: https://doi.org/10.1101/2020.09.11.20192419; this version posted September 13, 2020. The copyright holder for this preprint (which was not certified by peer review) is the author/funder, who has granted medRxiv a license to display the preprint in perpetuity.

PLOS ONE Submission It is made available under a CC-BY 4.0 International license .

Landsman et al.

\section{Abstract}

\section{Background}

58 Tuberculosis (TB) is a major cause of death worldwide. TB research draws heavily on clinical

59 cohorts which can be generated using electronic health records (EHR), but granular information

60 extracted from unstructured EHR data is limited. The St. Michael's Hospital TB database (SMH-

61 TB) was established to address gaps in EHR-derived TB clinical cohorts and provide researchers

62 and clinicians with detailed, granular data related to TB management and treatment.

\section{Methods}

64 We collected and validated multiple layers of EHR data from the TB outpatient clinic at St.

65 Michael's Hospital, Toronto, Ontario, Canada to generate the SMH-TB database. SMH-TB

66 contains structured data directly from the EHR, and variables generated using natural language

67 processing (NLP) by extracting relevant information from free-text within clinic, radiology, and

68 other notes. NLP performance was assessed using recall, precision and $\mathrm{F}_{1}$ score averaged across

69 variable labels. We present characteristics of the cohort population using binomial proportions

70 and $95 \%$ confidence intervals (CI), with and without adjusting for NLP misclassification errors.

\section{$71 \quad$ Results}

72 SMH-TB currently contains retrospective patient data spanning 2011 to 2018, for a total of 3298

73 patients ( $\mathrm{N}=3237$ with at least 1 associated dictation). Performance of TB diagnosis and

74 medication NLP rulesets surpasses $93 \%$ in recall, precision and $F_{1}$ metrics, indicating good

75 generalizability. We estimated $20 \%$ (95\% CI: 18.4-21.2\%) were diagnosed with active TB and

$76 \quad 46 \%$ (95\% CI: 43.8-47.2\%) were diagnosed with latent TB. After adjusting for potential

77 misclassification, the proportion of patients diagnosed with active and latent TB was $18 \%(95 \%$

78 CI: $16.8-19.7 \%$ ) and 40\% (95\% CI: 37.8-41.6\%) respectively

\section{Conclusion}

SMH-TB is a unique database that includes a breadth of structured data derived from structured

81 and unstructured EHR data. The data are available for a variety of research applications, such as

82 clinical epidemiology, quality improvement and mathematical modelling studies. 
medRxiv preprint doi: https://doi.org/10.1101/2020.09.11.20192419; this version posted September $13,2020$. The copyright holder for this preprint (which was not certified by peer review) is the author/funder, who has granted medRxiv a license to display the preprint in perpetuity.

PLOS ONE Submission

It is made available under a CC-BY 4.0 International license .

Landsman et al.

\section{Introduction}

Tuberculosis (TB) is the top infectious killer worldwide, resulting in 1.6 million deaths in 2017 (1). 1.7 billion people carry the latent form of the infection, of whom $10 \%$ at minimum, will develop the active, infectious form of disease. Latent TB infection (LTBI) progression to active disease can be prevented and TB can be cured, with appropriate antibiotics taken over many months. TB is endemic in many low-income countries and particularly prevalent in Asia and Africa. The World Health Organization recommends the treatment of LTBI as part of the global "End TB Strategy", and an achievable goal critical to TB elimination in high-income countries $(2,3)$.

Given the burden of active TB disease is disproportionately carried in low-resource settings, research addressing disease epidemiology, treatment (including clinical trials and programs of delivery), and the use and utility of innovative and point of care diagnostics is often completed in the populations of countries with highest burden of TB. The prevalence of LTBI on the other hand, is considerable even in high-income countries (CDC estimates 13,000,000 people living the USA have LTBI (4)) and thus research ranging from basic pathogenesis to program development can be conducted on the global population. Indeed while advances in biomedical research over the past 1 to 2 decades have delivered successes ranging from rapid point-of-care diagnostics testing for pulmonary TB to the development of novel therapeutics such as bedaquiline and delamanid, many questions remain, including, for example, discovering biomarkers that precisely indicate individuals at risk of LTBI activation and developing programs of TB care that ensure efficacy, are equitable and resilient $(1,5)$.

Many primary care practices and hospitals in high-income countries have curated electronic health record (EHR) data for research and surveillance (6-9), that improve ease of access to information and data sharing for collaborative work. The use of EHRs in hospital and officebased clinical practices has risen substantially in the past decade, providing rich data sources that have the potential to simultaneously improve patient care and advance research initiatives $(10,11)$. Most EHR-derived databases are however limited to structured data, such as demographic information collected at patient registration, laboratory tests and results and diagnostic codes used in physician billing. As such, the rich, granular data embedded within unstructured (text) data from dictated notes on both hospital admitted and clinic patients are excluded $(12,13)$ unless these variables are abstracted via manual chart review $(14,15)$ or natural language processing (NLP) (16-18). We developed the first digital retrospective clinical database that combines structured data, unstructured (text) data, and variables derived from transforming unstructured data to structured data using natural language rulesets, among patients assessed in an inner-city outpatient TB clinic at St Michaels Hospital (SMH) of Unity Health Toronto in Toronto, Ontario, Canada. 
medRxiv preprint doi: https://doi.org/10.1101/2020.09.11.20192419; this version posted September 13 , 2020. The copyright holder for this preprint (which was not certified by peer review) is the author/funder, who has granted medRxiv a license to display the preprint in perpetuity.

PLOS ONE Submission It is made available under a CC-BY 4.0 International license .

Landsman et al.

Approximately 2000 people (5.6 per 100,000 people) are diagnosed with active TB in Canada (19) annually and 1.3 million are estimated to have LTBI. The SMH TB clinic cares exclusively for individuals with suspected or diagnosed active TB and LTBI, seeing 1800-2200 patient-visits each year, and assessing and developing a diagnostic and management plan for 670-800 new patients each year.

In this paper we describe the SMH-TB database, which aims to be a resource for scientists who are conducting research into many facets of $\mathrm{TB}$, ranging from observational epidemiology to emulated trials and quality improvement and implementation science research. The purpose of this profile is to describe our methodology, present the cohort and the database validation. Access to the database is available to collaborators wishing to work with the research team of the SMH TB clinic. The NLP rulesets developed to extract variables from the unstructured data in the EHR are publicly available on GitHub (20).

\section{Materials and methods}

\section{Cohort Description}

The database compiles all data available on all TB clinic patients $(\mathrm{N}=3298)$ treated at $\mathrm{SMH}$ from April 2011 to December 2018. The database contains socio-demographic information surrounding immigration, housing status, and insurance, and clinical information including laboratory and imaging results, co-morbidities, diagnoses and treatment. Ethics approval for development and validation of the database was obtained from the Unity Health Toronto Research Ethics Board (REB 19-080). Patient consent was not required or obtained as per the Tri-Council Policy Statement 2 (TCPS2), since only retrospective data were collected from clinical charts (21).

Patients are referred to the TB outpatient clinic predominantly from Public Health Units in the Greater Toronto area (population of 6 million), Canada Immigration and Citizenship, Occupational Health and Safety Departments of Toronto area hospitals, community health care professionals (physicians, nurse-practitioners), and SMH staff physicians caring for an admitted patient or a patient in the emergency room (ER). When including a patient in our database we consider all available encounters, including inpatient admissions and ER visits.

\section{Data Collection}

St. Michael's Hospital EHR is managed by several systems. The Enterprise Data Warehouse (EDW) stores and manages structured data including patient demographics and medical test results. Soarian stores the unstructured patient data, which includes dictated clinical notes. SMHTB retrieved data of patients registered and assessed in the TB outpatient clinic to provide a comprehensive description of patient characteristics, disease, management and clinical trajectory. 
medRxiv preprint doi: https://doi.org/10.1101/2020.09.11.20192419; this version posted September 13, 2020. The copyright holder for this preprint (which was not certified by peer review) is the author/funder, who has granted medRxiv a license to display the preprint in perpetuity.

PLOS ONE Submission

It is made available under a CC-BY 4.0 International license.

154 SMH-TB is restricted to a start-date of April 2011, which is the date of initiation of EHR at

155 SMH. Fig 1 shows the data flow and data sources for the SMH-TB database.

156 Fig 1: Data sources for SMH-TB Database

157 The SMH-TB database stores patient characteristics and encounter data in separate tables, which 158 can be linked together using unique, de-identified patient or encounter IDs. Fig 2 presents the 159 tables provided in SMH-TB, and the granularity of the data they contain. A detailed collection of 160 all the variables available in the database is provided in Table 1.

Fig 2: Patient-level and Encounter-level Data in SMH-TB

\section{Table 1: Variables available in SMH-TB from both structured and unstructured sources}

\begin{tabular}{|l|l|}
\hline Demographics & Tuberculosis Diagnosis \\
\hline Patient ID & Known TB exposure* \\
\hline MRN & BCG vaccination status* \\
\hline Sex & TST performed* \\
\hline Date of birth & TST induration* \\
\hline Street address & TST interpretation* \\
\hline Postal code & \\
\hline Country of origin* & IGRA performed* \\
\hline Year of immigration* & IGRA interpretation* \\
\hline Immigration status & Diagnosis of active TB* \\
\hline Housing status & Diagnosis of LTBI* \\
\hline Insurance status & Ever started pyrazinamide* \\
\hline Patient is a healthcare worker* & Ever started ethionamide* \\
\hline Encounter Details & Ever started isoniazid* \\
\hline Encounter type & Ever started rifampin* ${ }^{*}$ \\
\hline & Medications \\
\hline
\end{tabular}


medRxiv preprint doi: https://doi.org/10.1101/2020.09.11.20192419; this version posted September 13, 2020. The copyright holder for this preprint (which was not certified by peer review) is the author/funder, who has granted medRxiv a license to display the preprint in perpetuity.

PLOS ONE Submission

It is made available under a CC-BY 4.0 International license .

Landsman et al.

\begin{tabular}{|c|c|}
\hline Encounter date & \\
\hline Direct $\cos \mathrm{t}^{\mathrm{b}}$ & Medical Conditions and Comorbidities \\
\hline \multirow[t]{2}{*}{ Indirect $\operatorname{cost}^{\mathrm{c}}$} & Autoimmune conditions ${ }^{\mathrm{d} *}$ \\
\hline & Diabetes* \\
\hline Aggregate Variables & Hematological malignancy* \\
\hline Number of sputum inductions & Non-hematological malignancy* \\
\hline Number of chest $\mathrm{x}$-rays & Transplant performed* \\
\hline Number of chest computed tomography & Renal failure $^{\mathrm{e}_{*}}$ \\
\hline $\begin{array}{l}\text { Hospital admission during course of TB } \\
\text { outpatient care }\end{array}$ & Silicosis* \\
\hline \multirow{2}{*}{$\begin{array}{l}\text { Number of emergency room visits during } \\
\text { course of TB outpatient care }\end{array}$} & Hepatitis B \\
\hline & Hepatitis C \\
\hline Laboratory Results & HIV status* \\
\hline \multicolumn{2}{|l|}{ AST } \\
\hline ALT & Microbiology Reports** \\
\hline CBC (Hb, Platelets, WBC) & Radiology Reports** \\
\hline $\mathrm{Cr}$ & Pathology Reports** \\
\hline Bilirubin & \\
\hline
\end{tabular}

MRN: Medical record number; AST: Aspartate transaminase; ALT: Alanine transaminase; CBC:

164 Complete blood count; Hb: Hemoglobin; WBC: White blood cells; Cr: Creatinine; TB: Tuberculosis; BCG: Bacillus Calmette-Guérin; TST: Tuberculin sensitivity test; IGRA: Interferon gamma release

$167{ }^{a}$ The database only stores the Forward Sortation Area portion of the postal code of the patient's residence.

$168{ }^{b}$ Direct cost corresponds to health care services directly associated with the patient's care including all 169 nursing, allied health, diagnostic and therapeutic services, pharmaceutical and medical/surgical supplies 170 for each visit.

$171{ }^{\mathrm{c}}$ Indirect cost corresponds to administrative and support services performed on behalf of all patients

172 including information system and housekeeping overheads. 
medRxiv preprint doi: https://doi.org/10.1101/2020.09.11.20192419; this version posted September 13 , 2020. The copyright holder for this preprint (which was not certified by peer review) is the author/funder, who has granted medRxiv a license to display the preprint in perpetuity.

It is made available under a CC-BY 4.0 International license.

PLOS ONE Submission

Landsman et al.

173

174

175

176

177

178

179

180

181

182

183

184

185

186

187

188

189

190

191

192

193

194

195

196

197

198

199

200

201

202

203

204

205

206

207

208

209

dAutoimmune conditions include: Sjogren's syndrome, arthropathy, spondyloarthropathy, psoriatic arthritis, rheumatoid arthritis, reactive arthritis, mixed connective tissue disease, connective tissue disease, systemic lupus erythematosus, CREST syndrome, dermatomyositis, Wegener's granulomatosis, Goodpasture syndrome, vasculitis and psoriasis.

${ }^{\mathrm{e}}$ Renal failure includes: nephropathy, renal insufficiency and glomerulonephritis.

*Variables collected from unstructured dictations and reports using natural language rulesets

**Unstructured text from which variables will be generated using natural language rulesets

\section{Removing identifiable information}

There are two versions of SMH-TB. The full version includes indelible patient identifiers such as a patient's provincial health insurance (Ontario Health Insurance Plan) number; their SMHspecific medical record number; all patient encounters whose encounter record is specific to a given patient; laboratory test records whose encounter record is also specific to a given patient; and all unstructured text data per encounter per patient. The patient identifiers allow for a fully linked database, which can be updated and linked via future data extraction. The identifiable unstructured data are also retained to support the development and testing of additional natural language rulesets.

The de-identified version of SMH-TB is the version that will be primarily used for research studies. It excludes the unstructured data and has been stripped of the following: hospital patient ID, hospital encounter ID, address and day and month of date of birth. Each patient and encounter is then re-coded with new unique IDs, and with the age in years on the date of the first TB clinic encounter

\section{Patient identification and validation}

The Decision Support Services (DSS) at SMH identified encounters which were coded as services provided in the TB outpatient clinic to identify all TB patients. We then randomly selected a list of 200 patients seen in the TB outpatient clinic (using clinic schedules with unique patient identifiers stored separately from the EDW) to manually validate the codes used by DSS to identify TB clinic outpatients, and validated that all (100\%) identified patients were registered in the TB clinic. To ensure high specificity of our identification of TB clinic patients, we examined additional metadata (such as a mention of the TB clinic in the patient's dictations) and removed patients without matching metadata. SMH-TB therefore may include the rare patient where the clinic visit codes in the EDW erroneously labelled a visit as a TB clinic visit, but this estimate is expected to be $<0.2 \%$ because of the additional metadata checks. The hospital unique patient identifier for each individual was then cross referenced to lists of all individuals with inpatient stays and ER visits to derive TB patient data from all sites of contact for TB care.

\section{Data transformation (unstructured text to structured variables)}

Unstructured clinician dictations were used to create patient-level variables on demographics, TB diagnosis, TB medications and comorbidities. The data for these variables were extracted using 
medRxiv preprint doi: https://doi.org/10.1101/2020.09.11.20192419; this version posted September $13,2020$. The copyright holder for this preprint (which was not certified by peer review) is the author/funder, who has granted medRxiv a license to display the preprint in perpetuity.

It is made available under a CC-BY 4.0 International license.

PLOS ONE Submission

Landsman et al.

210

211

212

213

214

215

216

217

218

219

220

221

222

223

224

225

226

227

228

229

230

231

232

233

234

235

236

237

238

239

240

241

242

243

244

245

246

rule-based information extraction tool CHARTextract (22). CHARTextract uses regular expressions in order to perform pattern matching on text. Regular expressions have been used to perform data extraction and even classification due to their high expressivity $(17,23,24)$. These capabilities come at the cost of a complex syntax, and thus rule creation typically involves the expertise of a clinician who understands the subject matter and an interpreter who can express the idea into regular expression syntax. We created a tiered rule system, where primary rules are used to filter text at the sentence level using a scoring system and secondary rules can be used to further enhance the weighting of the sentence. The tool applies the user-created rules to the data and extracts the variables on-the-fly. The interface displays mismatches between the tool prediction and the gold-standard label. Users can iterate on the rule creation process, allowing for easy refinement and quick development of the rules. Fig 3 shows a component of a ruleset for extracting diagnosis of active tuberculosis.

\section{Fig 3: Example of a component of a ruleset for extracting a variable (active TB diagnosis)} from unstructured text in clinical dictations (using CHARTextract)

In order to create the rulesets used by CHARTextract, two clinicians (JB, SM) from the TB outpatient clinic were consulted on dictation language and style. Clinicians (JB, SM, AA, and $\mathrm{KC}$ ) and a medical student (CW) manually labeled dictations for 200 patients from a subset of the dataset to be used for validation. The set of 200 patients was selected from consecutive clinic visits based on registered patient lists external to the EHR. This was done using the QuickLabel tool which provides a user interface for streamlined labelling of specific variables, as well as the option to label multiple variables simultaneously (25). Refinement of the natural language rulesets was done by comparing the labels extracted by the rulesets via CHARTextract with the manual labels. The refined rulesets are available as a real-time source as additional variables from unstructured data (microbiology, radiology, and pathology reports) are generated (20).

\section{Evaluation of data extraction}

To measure the performance of our rulesets and evaluate their generalizability to unseen data, we calculated accuracy, recall, precision and $\mathrm{F}_{1}$ scores. Recall (sensitivity) measures the ability of the classifier to correctly distinguish true positive from false negative examples. Precision (positive predictive value) measures the ability of the classifier to correctly distinguish true positive from false positive examples. The $\mathrm{F}_{1}$ score computes a harmonic mean of precision and recall. Recall, precision and $\mathrm{F}_{1}$ score were averaged across variable labels.

\section{Binomial proportions estimated from extracted variables}

We used the refined rulesets to extract variables from the full dataset of patients with at least 1 dictation (N=3237). We converted "Yes/No/Not recorded" and "Positive/Negative/Unknown/Not recorded" variables into binary 0-1 variables by assigning a value of 1 to patients with an extracted value of "Yes" or "Positive", and a value of 0 otherwise. We estimated the proportion and $95 \%$ confidence intervals of patients for which the rulesets extracted "Yes" or "Positive" for 
medRxiv preprint doi: https://doi.org/10.1101/2020.09.11.20192419; this version posted September 13, 2020. The copyright holder for this preprint (which was not certified by peer review) is the author/funder, who has granted medRxiv a license to display the preprint in perpetuity.

PLOS ONE Submission It is made available under a CC-BY 4.0 International license .

247 these variables using two methods: (1) logistic regression model without covariates, and (2) MC-

248 SIMEX model that accounts for the misclassification error in the extracted variables that was

249 calculated from the set of 200 manually abstracted patients (26). Briefly, for a binary random

250 variable $\mathrm{Y}$, we estimate the probability $\mathrm{P}(\mathrm{Y}=1)$ using a logistic regression model without

251 covariates, given by:

$$
P(Y=1)=h\left(\beta_{0}\right)
$$

252 where $\mathrm{h}$ is the logistic function. Under the MC-SIMEX model, the binary random variable was 253 observed with misclassification errors, denoted by $Y^{*}$. We estimate the probability $\mathrm{P}\left(Y^{*}=1\right)$ as:

$$
\mathrm{P}\left(Y^{*}=1\right)=\mathrm{h}\left(\beta_{0}^{*}\right)
$$

254 where $\beta_{0}{ }^{*}$ is defined as:

$$
\beta_{0}^{*}(\lambda)=h^{-1}\left[\pi_{11}^{\lambda} h\left(\beta_{0}\right)+\left(1-\pi_{00}^{\lambda}\right)\left(1-h\left(\beta_{0}\right)\right)\right]
$$

$\pi_{00}$ and $\pi_{11}$ denote the specificity and sensitivity of $Y^{*}$, respectively, and $\lambda$ is the misclassification parameter. The final estimate for $\beta_{0}{ }^{*}$ is computed by a simulation-extrapolation

257 procedure described in (26).

\section{Results}

\section{Population}

A patient overview based on demographics is presented in Table 2. 3298 patients were included in the database. The median age of the patients is 45 years, with an interquartile range of 34 to 58. There is a higher percentage of females than males in the cohort, around $57 \%$. At least $79 \%$ of the clinic patients were born outside of Canada, based on data extracted from patients' dictations. The vast majority of patients were adequately housed, with publicly funded provincial health care insurance (OHIP).

Table 2: Demographics of the patients included in the SMH-TB database, 2011-2018.

\begin{tabular}{|l|l|l|l}
\hline Variable & Value & \multicolumn{2}{|l}{$\begin{array}{l}\text { Number of patients who attended at least 1 } \\
\text { clinic visit (Total N=3298) }\end{array}$} \\
\cline { 3 - 4 } & & Count & Percentage \\
\hline \multirow{2}{*}{$\begin{array}{l}\text { Age-group in years } \\
\text { (median: 45, IQR: 34-58) }\end{array}$} & $10-20$ & 7 & 0.212 \\
\cline { 2 - 4 } & $20-30$ & 422 & 12.8 \\
\cline { 2 - 4 } & $30-40$ & 802 & 24.3 \\
\hline
\end{tabular}


medRxiv preprint doi: https://doi.org/10.1101/2020.09.11.20192419; this version posted September 13, 2020. The copyright holder for this preprint (which was not certified by peer review) is the author/funder, who has granted medRxiv a license to display the preprint in perpetuity.

PLOS ONE Submission

It is made available under a CC-BY 4.0 International license .

\begin{tabular}{|c|c|c|c|}
\hline & $40-50$ & 705 & 21.4 \\
\hline & $50-60$ & 575 & 17.4 \\
\hline & $60-70$ & 388 & 11.8 \\
\hline & $70-80$ & 245 & 7.42 \\
\hline & $80-90$ & 126 & 3.82 \\
\hline & $90-100$ & 30 & 0.910 \\
\hline & $100-110$ & 2 & 0.0606 \\
\hline $\operatorname{Sex}$ & Female & 1884 & 57.1 \\
\hline & Male & 1417 & 42.9 \\
\hline & Missing $^{\mathrm{a}}$ & 1 & 0.0303 \\
\hline Born in Canada & Born in Canada & 247 & 7.48 \\
\hline & Born outside Canada & 2619 & 79.3 \\
\hline & Missing $^{\mathrm{b}}$ & 436 & 13.2 \\
\hline Underhoused $^{c}$ & Yes & 80 & 2.42 \\
\hline & No & 3222 & 97.6 \\
\hline Type of health insurance ${ }^{d}$ & $\begin{array}{l}\text { Ontario Health Insurance Plan } \\
\text { (OHIP) }\end{array}$ & 2859 & 86.6 \\
\hline & $\begin{array}{l}\text { Uninsured Person Program } \\
\text { (TB-UP) }\end{array}$ & 221 & 6.69 \\
\hline & Refugee Health Coverage & 78 & 2.36 \\
\hline & $\begin{array}{l}\text { University Health Insurance } \\
\text { Plan (UHIP) }\end{array}$ & 41 & 1.24 \\
\hline & Self-payed & 76 & 2.30 \\
\hline & Other $^{\mathrm{e}}$ & 27 & 0.819 \\
\hline
\end{tabular}

IQR: Interquartile range

Landsman et al.

$268{ }^{a}$ May be due to error in data entry at time of patient registration.

$269{ }^{\mathrm{b}}$ Patient dictations did not mention immigration status or country of birth, or no dictations were found. 
medRxiv preprint doi: https://doi.org/10.1101/2020.09.11.20192419; this version posted September 13, 2020. The copyright holder for this preprint (which was not certified by peer review) is the author/funder, who has granted medRxiv a license to display the preprint in perpetuity.

PLOS ONE Submission

It is made available under a CC-BY 4.0 International license .

${ }^{c}$ Underhoused: includes patients living in homeless shelters, group homes or patients with no fixed address.

${ }^{\mathrm{d}}$ For patients with more than one type of insurance, only the insurance type used for the latest encounter is displayed in this table.

${ }^{\mathrm{e}}$ Includes any patients with an out-of-province insurance, or not recorded insurance type.

\section{Evaluation of data extraction}

A summary of the rulesets' performance metrics for the 25 variables extracted from unstructured dictations is presented in Table 3. Diagnosis of active TB and LTBI rulesets had $97.5 \%$ and $96 \%$ accuracy, and $97.4 \%$ and $94.7 \% \mathrm{~F}_{1}$ score, respectively. Rulesets for extracting $\mathrm{TB}$ medications generally achieved above $90 \%$ accuracy, recall and precision metrics.

Table 3: Summary of performance metrics on test set for variables extracted from unstructured dictations. Patients included in test set: $\mathbf{N}=\mathbf{2 0 0}$.

\begin{tabular}{|c|c|c|c|c|c|c|}
\hline Variable & $\begin{array}{l}\text { True } \\
\text { Positive* }\end{array}$ & $\begin{array}{l}\text { True } \\
\text { Negative* }\end{array}$ & Accuracy & Recall & Precision & $F_{1}$ Score \\
\hline \multicolumn{7}{|l|}{ Demographics } \\
\hline Country of origin & -- & -- & 0.970 & 0.987 & 0.987 & 0.986 \\
\hline $\begin{array}{l}\text { Year of } \\
\text { immigration }\end{array}$ & -- & -- & 0.805 & 0.834 & 0.891 & 0.850 \\
\hline $\begin{array}{l}\text { Patient is a } \\
\text { healthcare worker }\end{array}$ & 29 & 171 & 0.940 & 0.850 & 0.897 & 0.871 \\
\hline \multicolumn{7}{|c|}{ Tuberculosis Diagnosis } \\
\hline $\begin{array}{l}\text { Known TB } \\
\text { exposure }\end{array}$ & 43 & 157 & 0.965 & 0.952 & 0.945 & 0.949 \\
\hline $\begin{array}{l}\text { BCG vaccination } \\
\text { status }\end{array}$ & 89 & 111 & 0.865 & 0.852 & 0.887 & 0.859 \\
\hline TST performed & 100 & 100 & 0.990 & 0.990 & 0.990 & 0.990 \\
\hline TST induration & -- & -- & 0.985 & 0.954 & 0.960 & 0.957 \\
\hline TST interpretation & 86 & 114 & 0.980 & 0.978 & 0.981 & 0.980 \\
\hline IGRA performed & 14 & 186 & 1.00 & 1.00 & 1.00 & 1.00 \\
\hline
\end{tabular}


medRxiv preprint doi: https://doi.org/10.1101/2020.09.11.20192419; this version posted September 13, 2020. The copyright holder for this preprint (which was not certified by peer review) is the author/funder, who has granted medRxiv a license to display the preprint in perpetuity.

It is made available under a CC-BY 4.0 International license .

PLOS ONE Submission

Landsman et al.

\begin{tabular}{|c|c|c|c|c|c|c|}
\hline $\begin{array}{l}\text { IGRA } \\
\text { interpretation }\end{array}$ & 5 & 195 & 1.00 & 1.00 & 1.00 & 1.00 \\
\hline $\begin{array}{l}\text { Diagnosis of } \\
\text { active TB }\end{array}$ & 120 & 80 & 0.975 & 0.975 & 0.973 & 0.974 \\
\hline Diagnosis of LTBI & 49 & 151 & 0.960 & 0.953 & 0.941 & 0.947 \\
\hline \multicolumn{7}{|c|}{ Tuberculosis Medications } \\
\hline $\begin{array}{l}\text { Ever started } \\
\text { isoniazid }\end{array}$ & 150 & 50 & 0.960 & 0.933 & 0.959 & 0.945 \\
\hline $\begin{array}{l}\text { Ever started } \\
\text { rifampin }\end{array}$ & 127 & 73 & 0.970 & 0.962 & 0.974 & 0.967 \\
\hline $\begin{array}{l}\text { Ever started } \\
\text { pyrazinamide }\end{array}$ & 124 & 76 & 0.995 & 0.996 & 0.994 & 0.995 \\
\hline $\begin{array}{l}\text { Ever started } \\
\text { ethambutol }\end{array}$ & 118 & 82 & 0.985 & 0.985 & 0.984 & 0.984 \\
\hline $\begin{array}{l}\text { Ever started } \\
\text { vitamin B6 }\end{array}$ & 147 & 53 & 0.990 & 0.987 & 0.987 & 0.987 \\
\hline \multicolumn{7}{|c|}{ Medical Conditions and Comorbidities** } \\
\hline $\begin{array}{l}\text { Autoimmune } \\
\text { conditions }\end{array}$ & 8 & 192 & 0.965 & 0.862 & 0.767 & 0.807 \\
\hline Diabetes & 26 & 174 & 0.945 & 0.870 & 0.883 & 0.876 \\
\hline $\begin{array}{l}\text { Hematological } \\
\text { malignancy }\end{array}$ & 2 & 198 & 0.990 & 0.748 & 0.748 & 0.748 \\
\hline $\begin{array}{l}\text { Non- } \\
\text { hematological } \\
\text { malignancy }\end{array}$ & 12 & 188 & 0.955 & 0.937 & 0.787 & 0.843 \\
\hline Renal failure & 8 & 192 & 0.975 & 0.807 & 0.849 & 0.827 \\
\hline HIV status & 2 & 198 & 0.995 & 0.998 & 0.833 & 0.899 \\
\hline
\end{tabular}

TB: Tuberculosis; BCG: Bacillus Calmette-Guérin; TST: Tuberculin sensitivity test; IGRA: Interferon gamma release assay; LTBI: Latent tuberculosis infection; HIV: Human immunodeficiency viruses 
medRxiv preprint doi: https://doi.org/10.1101/2020.09.11.20192419; this version posted September 13, 2020. The copyright holder for this preprint (which was not certified by peer review) is the author/funder, who has granted medRxiv a license to display the preprint in perpetuity.

PLOS ONE Submission It is made available under a CC-BY 4.0 International license .

*True positives are defined as observations with a value of "Yes" or "Positive"; True negatives are defined as the complement of true positives; only applicable for extracted variables which have "Yes/No/Not recorded" or "Positive/Negative" values.

**Patients that had undergone a transplant and patients diagnosed with silicosis were excluded from this table due to having no positive example in the test set.

\section{Binomial proportions estimated from extracted variables}

The estimated proportions and their 95\% confidence intervals created from the "Yes/No/Not recorded" and "Positive/Negative" extracted variables are given in Table 4.

Table 4: Binomial proportion estimate and $95 \%$ confidence interval (CI) using standard binary regression and MC-SIMEX model for binary variables created from extracted variables. Total patients with at least 1 dictation: $\mathbf{N}=3237$.

\begin{tabular}{|l|l|l|l|}
\hline \multicolumn{2}{|l|}{$\begin{array}{l}\text { Count } \\
\text { Description }\end{array}$} & $\begin{array}{l}\text { Logistic regression } \\
\text { estimate } \\
(95 \% \mathrm{CI})\end{array}$ & $\begin{array}{l}\text { MC-SIMEX model estimate } \\
(95 \% \mathrm{CI})\end{array}$ \\
\hline Demographics & 438 & $\begin{array}{l}13.5 \% \\
(12.4,14.8)\end{array}$ & $\begin{array}{l}2.48 \% \\
(2.02,3.04)\end{array}$ \\
\hline Healthcare workers & \multicolumn{5}{|l|}{} \\
\hline Tuberculosis Diagnosis & 706 & $\begin{array}{l}21.8 \% \\
(20.4,23.3)\end{array}$ & $\begin{array}{l}16.8 \% \\
(15.3,18.3)\end{array}$ \\
\hline Known TB exposure & 1316 & $\begin{array}{l}40.7 \% \\
(39.0,42.4)\end{array}$ & $\begin{array}{l}24.8 \% \\
(23.0,26.7)\end{array}$ \\
\hline Received BCG vaccination & 2279 & $\begin{array}{l}70.4 \% \\
(68.8,72.0)\end{array}$ & $\begin{array}{l}69.7 \% \\
(68.1,71.3)\end{array}$ \\
\hline Performed a TST & 2031 & $\begin{array}{l}62.7 \% \\
(61.1,64.4)\end{array}$ & $\begin{array}{l}61.9 \% \\
(60.2,63.6)\end{array}$ \\
\hline $\begin{array}{l}\text { Received a positive TST } \\
\text { interpretation }\end{array}$ & 296 & $\begin{array}{l}9.14 \% \\
(8.20,10.2)\end{array}$ & $\begin{array}{l}9.14 \% \\
(8.20,10.2)\end{array}$ \\
\hline Performed an IGRA & $\begin{array}{l}9.30 \% \\
(8.35,10.3)\end{array}$ & $\begin{array}{l}9.30 \% \\
(8.35,10.3)\end{array}$ \\
\hline $\begin{array}{l}\text { Received a positive IGRA } \\
\text { interpretation }\end{array}$ & 301 & $\begin{array}{l}19.8 \% \\
(18.4,21.2)\end{array}$ & $\begin{array}{l}18.2 \% \\
(16.8,19.7)\end{array}$ \\
\hline Diagnosed with active TB & 640 & $\begin{array}{l}45.5 \% \\
(43.8,47.2)\end{array}$ & $\begin{array}{l}39.7 \% \\
(37.8,41.6)\end{array}$ \\
\hline Diagnosed with LTBI & 1473 & &
\end{tabular}


medRxiv preprint doi: https://doi.org/10.1101/2020.09.11.20192419; this version posted September 13, 2020. The copyright holder for this preprint (which was not certified by peer review) is the author/funder, who has granted medRxiv a license to display the preprint in perpetuity.

PLOS ONE Submission

It is made available under a CC-BY 4.0 International license .

\begin{tabular}{|c|c|c|c|}
\hline \multicolumn{4}{|l|}{ Tuberculosis Medications } \\
\hline Ever started on isoniazid & 1314 & $\begin{array}{l}40.6 \% \\
(38.9,42.3)\end{array}$ & $\begin{array}{l}45.6 \% \\
(43.6,47.5)\end{array}$ \\
\hline Ever started on rifampin & 548 & $\begin{array}{l}16.9 \% \\
(15.7,18.3)\end{array}$ & $\begin{array}{l}17.6 \% \\
(16.3,19.1)\end{array}$ \\
\hline $\begin{array}{l}\text { Ever started on } \\
\text { pyrazinamide }\end{array}$ & 349 & $\begin{array}{l}10.8 \% \\
(9.76,11.9)\end{array}$ & $\begin{array}{l}9.99 \% \\
(8.96,11.1)\end{array}$ \\
\hline Ever started on ethambutol & 348 & $\begin{array}{l}10.8 \% \\
(9.73,11.9)\end{array}$ & $\begin{array}{l}9.36 \% \\
(8.32,10.5)\end{array}$ \\
\hline Ever started on vitamin B6 & 986 & $\begin{array}{l}30.5 \% \\
(28.9,32.1)\end{array}$ & $\begin{array}{l}30.6 \% \\
(29.0,32.2)\end{array}$ \\
\hline \multicolumn{4}{|c|}{ Medical Conditions and Comorbidities* } \\
\hline Autoimmune conditions & 167 & $\begin{array}{l}5.16 \% \\
(4.45,5.98)\end{array}$ & $\begin{array}{l}0.259 \% \\
(0.175,0.383)\end{array}$ \\
\hline Diabetes & 179 & $\begin{array}{l}5.53 \% \\
(4.79,6.37)\end{array}$ & $\begin{array}{l}0.358 \% \\
(0.247,0.517)\end{array}$ \\
\hline Hematological malignancy & 71 & $\begin{array}{l}2.19 \% \\
(1.74,2.76)\end{array}$ & $\begin{array}{l}0.00625 \% \\
(0.00320,0.0122)\end{array}$ \\
\hline $\begin{array}{l}\text { Non-hematological } \\
\text { malignancy }\end{array}$ & 140 & $\begin{array}{l}4.32 \% \\
(3.68,5.08)\end{array}$ & $\begin{array}{l}0.860 \% \\
(0.599,1.23)\end{array}$ \\
\hline Renal failure & 65 & $\begin{array}{l}2.01 \% \\
(1.58,2.55)\end{array}$ & $\begin{array}{l}0.00895 \% \\
(0.00450,0.0180)\end{array}$ \\
\hline Diagnosed with HIV & 175 & $\begin{array}{l}5.41 \% \\
(4.68,6.24)\end{array}$ & $\begin{array}{l}5.43 \% \\
(4.69,6.26)\end{array}$ \\
\hline $\begin{array}{l}\text { No relevant medical } \\
\text { conditions/comorbidities** }\end{array}$ & 2569 & $\begin{array}{l}79.4 \% \\
(77.9,80.7)\end{array}$ & $\begin{array}{l}89.3 \% \\
(87.9,90.6)\end{array}$ \\
\hline
\end{tabular}

MC-SIMEX: Misclassification Simulation Extraction; CI: Confidence interval; TB: Tuberculosis; BCG:

297 Bacillus Calmette-Guérin; TST: Tuberculin sensitivity test; IGRA: Interferon gamma release assay;

298 LTBI: Latent tuberculosis infection; HIV: Human immunodeficiency viruses

299 *Patients that had undergone a transplant and patients diagnosed with silicosis were excluded from this

300 table due to having no positive example in the test set. 
medRxiv preprint doi: https://doi.org/10.1101/2020.09.11.20192419; this version posted September $13,2020$. The copyright holder for this preprint (which was not certified by peer review) is the author/funder, who has granted medRxiv a license to display the preprint in perpetuity.

PLOS ONE Submission It is made available under a CC-BY 4.0 International license.

Landsman et al.

301

302

303

304

305

306

307

308

309

310

311

312

313

314

315

316

317

318

319

320

321

322

323

324

325

326

327

328

329

330

331

332

333

334

335

336

***Includes any patient with an extracted value of "No/Not recorded/Negative" for all medical conditions/comorbidities listed in the table.

After accounting for misclassification errors, the proportion of patients with an active TB diagnosis was $18.2 \%$ and the proportion of patients with an LTBI diagnosis was $39.7 \% .69 .7 \%$ of patients had performed a tuberculin sensitivity test and $61.9 \%$ of all patients had a positive result for the test. The proportions of patients who were ever started on isoniazid, rifampin or B6 were $45.6 \%, 17.6 \%$ and $30.6 \%$ percent, respectively.

\section{Discussion}

To facilitate research on TB clinical epidemiology, diagnostics, clinical care and program implementation, quality improvement, and linkage for future therapeutics trials and biomarker studies, we developed a retrospective database of TB clinic patients using structured and unstructured EHR data. The cohort and database are unique in the transformation of unstructured data into structured variables using natural language rulesets with excellent performance when validated against manual chart abstraction. The rulesets are open access, and the database is accessible for research and open for collaboration with approval from local research ethics board.

The strength of the SMH-TB database comes from the inclusion of granular data, achieved by extracting it from unstructured sources using natural language processing. While the database contains standard structured data accessible in a wide variety of EHRs, a large and unique component of our data comes directly from unstructured dictated clinic notes, which contain a vast number of variables that can be used for a broad range of research topics, including, for example, clinical epidemiology and modelling studies. The NLP rulesets allow us to create granular patient-level variables from unstructured data accurately and efficiently, reducing the amount of time spent on manual abstraction to a minimum. Moreover, the large amount of unstructured raw data is a tremendous resource for evaluating and deploying machine learning and deep learning models capable of automatically extracting meaningful variables from clinical notes (27-29). Machine learning models and workflows can be developed to leverage the structured and extracted variables for predictive modeling and early warning systems (30-32). The breadth of data provided makes this a unique and powerful tool in both clinical and computational research.

The main limitations of the SMH-TB database include issues that arise from missing or incorrect data and the limited availability of data for certain variables leading to non-robust natural language rulesets. Data errors can be due to both human and algorithmic mistakes. Much of the burden of including relevant data in clinical dictations lies with the clinician attending the patient and dictating the note. In the absence of a standardized format, as was the case in the SMH TB clinic, variables may not be dictated in a manner that enables their capture by the NLP tools, or are not dictated at all. The creation of a shared set of guidelines and standard formatting for TB 
medRxiv preprint doi: https://doi.org/10.1101/2020.09.11.20192419; this version posted September 13 , 2020. The copyright holder for this preprint (which was not certified by peer review) is the author/funder, who has granted medRxiv a license to display the preprint in perpetuity.

PLOS ONE Submission It is made available under a CC-BY 4.0 International license .

Landsman et al.

337 clinic dictations, containing all variables relevant to the database, will ensure all data required are 338 captured with future database updates.

339 When the unstructured data undergoes information extraction, mislabeling of variables can occur 340 due to certain rulesets having subpar performance. This issue is especially apparent for variables 341 with scarce availability of labels. For example, in our validation dataset there were no patients 342 with silicosis. The ruleset for classifying silicosis was adapted from other immunosuppressive 343 conditions and expert knowledge in disease. While it is possible that such rulesets are overly 344 confident in assigning a "No" label to patients even if they present with the condition in 345 question, given the rarity of the event in the patient population it was not possible to provide 346 further cases for perfection of refinement of the NLP ruleset. As such, we have indicated the 347 metrics of our variables (Table 3), so that researchers can understand the limitations of the data 348 with which they are working. The 200 charts sampled for ruleset refinement were consecutive 349 patients from a set of clinic visits and may not have been sufficient for less common variables 350 such as comorbidities. That is, further ruleset refinement will be needed with additional charts 351 with purposive sampling of true positives of infrequent variables.

352

353

354

355

356

357

358

359

360

361

362

363

364

365

366

367

368

369

370

371

\section{Conclusion}

In summary, here we describe the SMH-TB cohort and database which aim to be a resource for scientists who are conducting research into many facets of TB. The database is unique in that it contains highly granular socio-demographic and clinical patient data derived from structured and unstructured EHR data extracted using NLP rule sets. The validated rule sets are provided open access for use and the data base is intended to be available for collaborative studies.

\section{Data Availability}

The validated NLP rulesets are publicly available for use from: https://github.com/mishra-lab/tbnlp-rulesets. Data collected in SMH-TB contains sensitive patient information and as such, researchers interested in conducting TB-related research using the data are welcome to contact the corresponding author and submit a request. The study team welcomes collaboration and use of the database, and all external requests will be screened to ensure adequate data exists to enable a collaboration. The project will then undergo the approval process of the Research and Ethics Board (REB) of Unity Health Toronto. Data provided to researchers can either be the deidentified version of the SMH-TB database, or the full identifiable version, based on their research needs and REB approval.

\section{Funding}

Supported by the Ontario Early Researcher Award Number ER17-13-043 (to SM). The funders had no role in study design, data collection and analysis, decision to publish, or preparation of the manuscript. 
medRxiv preprint doi: https://doi.org/10.1101/2020.09.11.20192419; this version posted September 13, 2020. The copyright holder for this preprint (which was not certified by peer review) is the author/funder, who has granted medRxiv a license to display the preprint in perpetuity.

PLOS ONE Submission It is made available under a CC-BY 4.0 International license.

\section{Acknowledgements}

373 We thank Dr. Natasha Sabur for supporting arbitration for rulesets; Julie Seemangal (TB

374 Outpatient Clinic Co-Lead) and Grace Bezaliel for supporting verification of algorithms to 375 classify patients seen in the TB clinic.

376 
medRxiv preprint doi: https://doi.org/10.1101/2020.09.11.20192419; this version posted September $13,2020$. The copyright holder for this preprint (which was not certified by peer review) is the author/funder, who has granted medRxiv a license to display the preprint in perpetuity.

PLOS ONE Submission It is made available under a CC-BY 4.0 International license .

\section{References}

378

379

380

381

382

383

384

385

386

387

388

389

390

391

392

393

394

395

396

397

398

399

400

401

402

403

404

405

406

407

408

409
1. Reid MJA, Arinaminpathy N, Bloom A, Bloom BR, Boehme C, Chaisson R, et al. Building a tuberculosis-free world: The Lancet Commission on tuberculosis. Lancet Lond Engl. 2019 Mar 30;393(10178):1331-84.

2. Uplekar M, Weil D, Lönnroth K, Jaramillo E, Lienhardt C, Dias HM, et al. WHO's new End TB Strategy. The Lancet. 2015 May 2;385(9979):1799-801.

3. Lönnroth K, Migliori GB, Abubakar I, D’Ambrosio L, Vries G de, Diel R, et al. Towards tuberculosis elimination: an action framework for low-incidence countries. Eur Respir J. 2015 Apr 1;45(4):928-52.

4. CDC. Deciding When to Treat Latent TB Infection [Internet]. 2018 [cited 2020 Aug 25]. Available from: https://www.cdc.gov/tb/topic/treatment/decideltbi.htm

5. Kim PS, Makhene M, Sizemore C, Hafner R. Viewpoint: Challenges and Opportunities in Tuberculosis Research. J Infect Dis. 2012 May 15;205(suppl_2):S347-52.

6. Busingye D, Gianacas C, Pollack A, Chidwick K, Merrifield A, Norman S, et al. Data Resource Profile: MedicineInsight, an Australian national primary health care database. Int J Epidemiol. 2019 Dec 1;48(6):1741-1741h.

7. Garies S, Birtwhistle R, Drummond N, Queenan J, Williamson T. Data Resource Profile: National electronic medical record data from the Canadian Primary Care Sentinel Surveillance Network (CPCSSN). Int J Epidemiol. 2017 Aug 1;46(4):1091-1092f.

8. Finer S, Martin HC, Khan A, Hunt KA, MacLaughlin B, Ahmed Z, et al. Cohort profile: East London genes \& health (ELGH), a community-based population genomics and health study of British Bangladeshi and British Pakistani people. Int J Epidemiol [Internet]. [cited 2020 Mar 2]; Available from: https://academic.oup.com/ije/advancearticle/doi/10.1093/ije/dyz174/5555939

9. Ashfaq A, Lönn S, Nilsson H, Eriksson JA, Kwatra J, Yasin ZM, et al. Data resource profile: Regional healthcare information platform in Halland, Sweden, a dedicated environment for healthcare research. Int J Epidemiol [Internet]. [cited 2020 Mar 2]; Available from: https://academic.oup.com/ije/advance-article/doi/10.1093/ije/dyz262/5701527

10. Office of the National Coordinator for Health Information Technology. Office-based Physician Electronic Health Record Adoption [Internet]. 2019 [cited 2020 Apr 7]. Available from: dashboard.healthit.gov/quickstats/pages/physician-ehr-adoption-trends.php

11. Henry J, Pylypchuk Y, Searcy T, Patel V. Adoption of electronic health record systems among US non-federal acute care hospitals: 2008-2015. ONC Data Brief. 2016;35:1-9. 
medRxiv preprint doi: https://doi.org/10.1101/2020.09.11.20192419; this version posted September 13 , 2020. The copyright holder for this preprint (which was not certified by peer review) is the author/funder, who has granted medRxiv a license to display the preprint in perpetuity.

PLOS ONE Submission It is made available under a CC-BY 4.0 International license.

12. Chan KS, Fowles JB, Weiner JP. Review: Electronic Health Records and the Reliability and Validity of Quality Measures: A Review of the Literature. Med Care Res Rev. 2010 Oct 1;67(5):503-27.

13. Nicholson A, Tate AR, Koeling R, Cassell JA. What does validation of cases in electronic record databases mean? The potential contribution of free text. Pharmacoepidemiol Drug Saf. 2011;20(3):321-4.

14. Khan K, Campbell A, Wallington T, Gardam M. The impact of physician training and experience on the survival of patients with active tuberculosis. CMAJ Can Med Assoc J. 2006 Sep 26;175(7):749-53.

15. Long R, Heffernan C, Gao Z, Egedahl ML, Talbot J. Do "Virtual” and "Outpatient" Public Health Tuberculosis Clinics Perform Equally Well? A Program-Wide Evaluation in Alberta, Canada. PLoS ONE [Internet]. 2015 Dec 23 [cited 2020 Apr 7];10(12). Available from: https://www.ncbi.nlm.nih.gov/pmc/articles/PMC4689372/

16. Baldwin KB. Evaluating Healthcare Quality Using Natural Language Processing. J Healthc Qual. 2008;30(4):24-9.

17. Luo Y, Thompson WK, Herr TM, Zeng Z, Berendsen MA, Jonnalagadda SR, et al. Natural Language Processing for EHR-Based Pharmacovigilance: A Structured Review. Drug Saf. 2017;40(11):1075-89.

18. Wang Y, Wang L, Rastegar-Mojarad M, Moon S, Shen F, Afzal N, et al. Clinical information extraction applications: A literature review. J Biomed Inform. 2018 Jan 1;77:3449.

19. WHO. Tuberculosis country profiles [Internet]. World Health Organization; [cited 2020 Apr 7]. Available from: http://www.who.int/tb/country/data/profiles/en/

20. Landsman D, LKS-CHART. Tuberculosis NLP Rulesets [Internet]. GitHub. [cited 2020 Jul 1]. Available from: https://github.com/mishra-lab/tb-nlp-rulesets

21. Government of Canada. Tri-Council Policy Statement: Ethical Conduct for Research Involving Humans - TCPS 2 (2018) [Internet]. 2019 [cited 2020 Aug 27]. Available from: https://ethics.gc.ca/eng/policy-politique_tcps2-eptc2_2018.html

22. LKS-CHART. CHARTextract [Internet]. CHARTextract. [cited 2020 Jun 29]. Available from: https://lks-chart.github.io/CHARTextract-docs/

23. Rosier A, Burgun A, Mabo P. Using regular expressions to extract information on pacemaker implantation procedures from clinical reports. AMIA Annu Symp Proc. 2008;2008:81-5.

24. Finley G, Edwards E, Robinson A, Brenndoerfer M, Sadoughi N, Fone J, et al. An automated medical scribe for documenting clinical encounters. In: Proceedings of the 2018 Conference of the North American Chapter of the Association for Computational Linguistics: Demonstrations [Internet]. New Orleans, Louisiana: Association for Computational 
medRxiv preprint doi: https://doi.org/10.1101/2020.09.11.20192419; this version posted September 13, 2020. The copyright holder for this preprint (which was not certified by peer review) is the author/funder, who has granted medRxiv a license to display the preprint in perpetuity.

PLOS ONE Submission It is made available under a CC-BY 4.0 International license.

446

447

448

449

450

451

452

453

454

455

456

457

458

459

460

461

462

463

464

465

466

467

468

469

470

471
Linguistics; 2018 [cited 2020 Jun 29]. p. 11-15. Available from:

https://www.aclweb.org/anthology/N18-5003

25. Joshi U. QuickLabel [Internet]. 2019 [cited 2020 Jun 29]. Available from: https://github.com/Sabrewarrior/QuickLabel

26. Küchenhoff H, Mwalili SM, Lesaffre E. A General Method for Dealing with Misclassification in Regression: The Misclassification SIMEX. Biometrics. 2006;62(1):8596.

27. Jagannatha AN, Yu H. Structured prediction models for RNN based sequence labeling in clinical text. Proc Conf Empir Methods Nat Lang Process Conf Empir Methods Nat Lang Process. 2016 Nov;2016:856-65.

28. Wu Y, Jiang M, Lei J, Xu H. Named Entity Recognition in Chinese Clinical Text Using Deep Neural Network. Stud Health Technol Inform. 2015;216:624-8.

29. Fries J. Brundlefly at SemEval-2016 Task 12: Recurrent Neural Networks vs. Joint Inference for Clinical Temporal Information Extraction. In: Proceedings of the 10th International Workshop on Semantic Evaluation (SemEval-2016) [Internet]. San Diego, California: Association for Computational Linguistics; 2016 [cited 2020 Aug 25]. p. 1274-1279. Available from: https://www.aclweb.org/anthology/S16-1198

30. Miotto R, Li L, Kidd BA, Dudley JT. Deep Patient: An Unsupervised Representation to Predict the Future of Patients from the Electronic Health Records. Sci Rep. 2016 May 17;6(1):26094.

31. Tran T, Nguyen TD, Phung D, Venkatesh S. Learning vector representation of medical objects via EMR-driven nonnegative restricted Boltzmann machines (eNRBM). J Biomed Inform. 2015 Apr 1;54:96-105.

32. Choi E, Bahadori MT, Schuetz A, Stewart WF, Sun J. Doctor AI: Predicting Clinical Events via Recurrent Neural Networks. JMLR Workshop Conf Proc. 2016 Aug;56:301-18. 


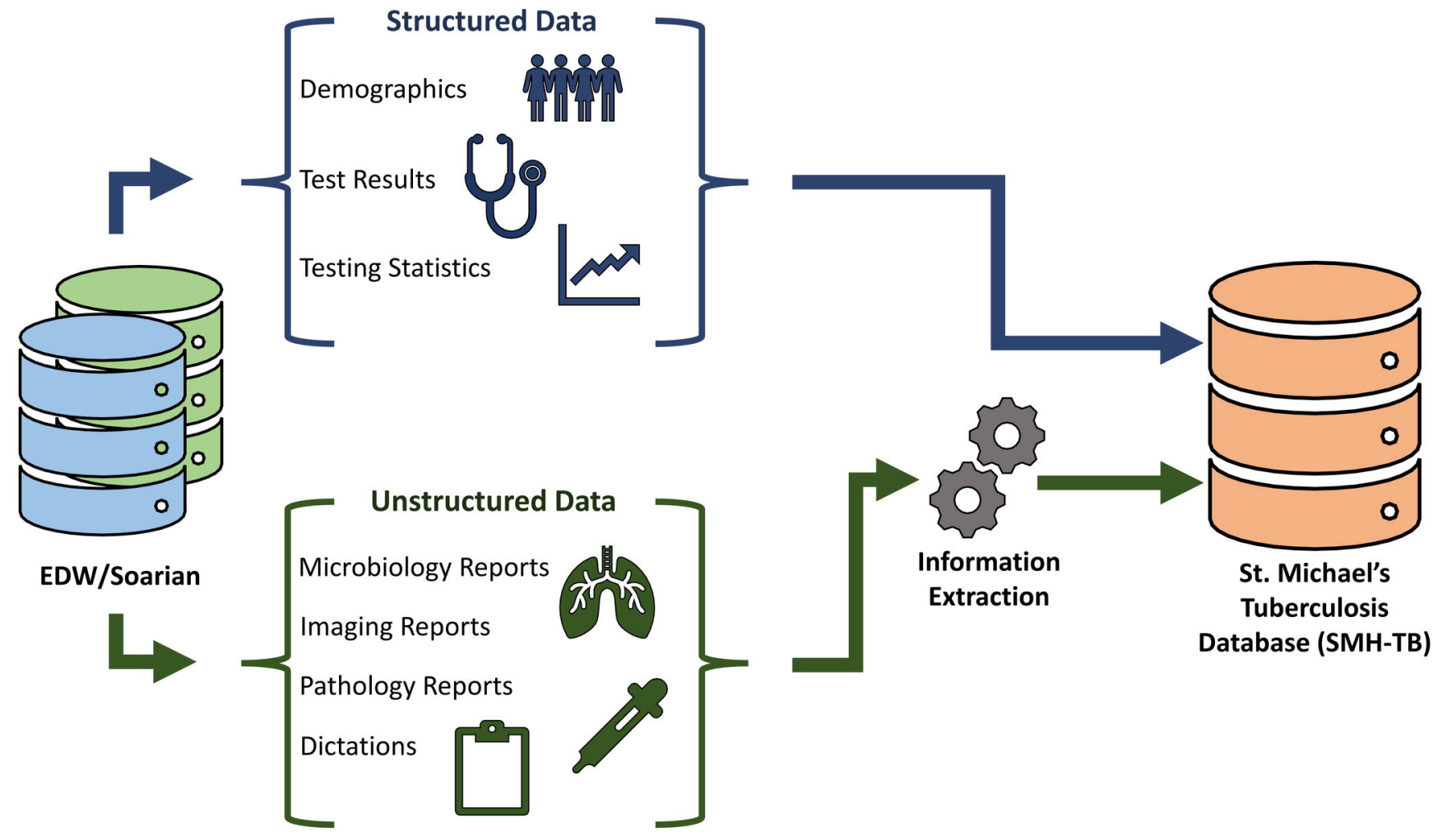




\section{Patient-Level}

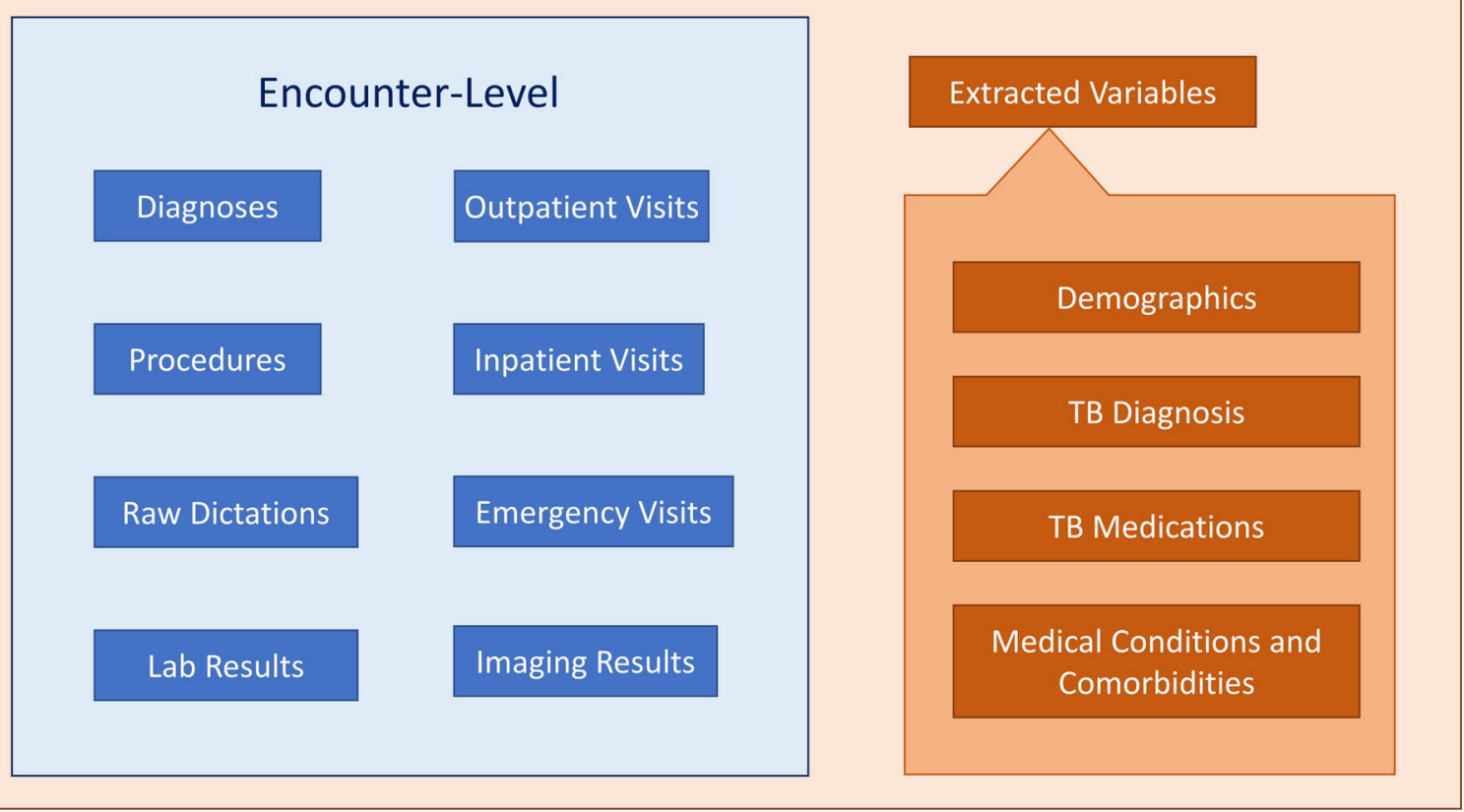




\section{appears, then score}

appears after 1 , then score

appears, then score $\checkmark$
0

3 